\title{
(5)
}

\section{O PENSAMENTO PÓS-MODERNO E OS DESAFIOS CONTEMPORÂNEOS AO PROJETO ÉTICO-POLÍTICO DO SERVIÇO SOCIAL}

\author{
Post-modern thought and the contemporary challenges to the ethical-political project of \\ social service
}

\author{
Bismarck Oliveira da Silva* \\ Maria Tereza de Oliveira**
}

\begin{abstract}
RESUMO
Este artigo analisa os impactos das teorias pós-modernas e de suas estratégias na realidade brasileira, no processo de implementação e consolidação dos projetos societários e profissionais. A metodologia utilizada para a concretização deste estudo foi a abordagem qualitativa, com caráter exploratório, e, para isso, foi necessária a utilização da revisão literária. O objetivo geral é desvelar elementos que expliquem, hoje, o direcionamento social estratégico do projeto profissional do Serviço Social brasileiro, mesmo com a aderência de alguns seguimentos profissionais às perspectivas pós-modernas e à descrença em metanarrativas que dão significado social à profissão. Os objetivos específicos pretendem: a) analisar como as teorias pós-modernas se expressam nos projetos societários e profissionais; b) discriminar o conjunto de estratégias utilizado pela categoria profissional na construção de uma direção social estratégica; e c) refletir acerca de uma contribuição expressiva do fenômeno da vontade potência na estruturação e articulação de projetos societários ouprofissionais. Em tempos de estratégias neoconservadoras e de crise orgânica, através da ampliação de poderes político-econômico patriarcais, patrimonialistas e segregadoras, a agenda do projeto societal burguês tem ocasionado retrocessos no âmbito das políticas públicas e setoriais. Nessa perspectiva, é possível identificar vitórias da direção ético-política da categoria dos assistentes sociais frente aos projetos societários convergentes. Nas considerações finais, espera-se proporcionar ao leitor um melhor entendimento dos processos de resistências às investidas do modelo político-econômico vigente.
\end{abstract}

\section{PALAVRAS-CHAVES}

Projeto profissional. Projeto societário. Neoconservadorismo. Pós-modernismo. Pós-neoliberalismo.

\section{ABSTRACT}

This paper analyses the impacts of postmodern theories and their strategies in Brazilian reality in the implementation and consolidation process of corporate and professional projects. The methodology used to carry out the study was a qualitative and exploratory approach, and for this, the use of literary revision was

\footnotetext{
* Assistente Social. Mestrando no Programa de Pós-Graduação em Estudos Urbanos e Regionais (UFRN). Assistente Social da Coordenadoria da Infância e Juventude (CEIJ) do Tribunal de Justiça do Rio Grande do Norte (TJRN). Praça 7 de setembro, s/n, Natal (RN), CEP.: 59025-300. ORC ID: <http://orcid.org/0000-00024562-6424>. E-mail: <bismarck.oliveirasilva@gmail.com>.

** Assistente Social e Filosófa. Mestra em Filosofia. Professora do Curso de Serviço Social do Centro Universitário Facex. R. Orlando Silva, 2896, Capim Macio, Natal (RN), CEP.: 59080-020. ORC ID: <https://orcid.org/0000-0003-4203-288X>. E-mail: <terezafilosofa6@gmail.com>.
}

DOI 10.22422/temporalis.2018v18n36p65-93 


\section{tempordilis}

necessary. The general objective is reveal elements that explain the strategic social direction of the professional project of the Brazilian Social Work even with the adherence of some professional follow-ups to postmodern perspectives and the disbelief in metanarratives that give social meaning to the profession. Specific objectives are: a) analyze how postmodern theories are expressed in corporate and professional projects $b$ ) discriminate the set of strategies used by professional category in building a strategic social direction and c) reflect on an expressive contribution of the willpower phenomenon in the structuring and articulation of either corporate or professional projects. In times of neoconservative strategies and organic crises, through the expansion of patriarchal political-economic, patrimonialists and segregators powers, the agenda of the bourgeois society project has caused setbacks in the scope of public and sectoral policies. In this perspective it is possible to identify victories of the ethical-political direction of the category of social workers in front of the convergent corporate projects. In the concluding remarks, it is hoped to provide the reader with a better understanding of the processes of resisting the onslaughts of the current political-economic model.

\section{KEYWORDS}

Professional project. Corporate project. Neoconservatism. Post-neoliberalism. Post-modernism.

\section{INTRODUÇÃO}

Trata-se de compreender, com este artigo, os impactos das teorias pós-modernas, seja do neopositivismo 1 , neoconservadorismo ${ }^{2}$ ou ecletismo 3 , diante do conjunto das estratégias utilizadas pelos profissionais segundo seu posicionamento político na defesa e consolidação dos projetos societários ${ }^{4}$ e profissionais 5 . Para isso, mobilizaram-se diferentes referenciais teóricos que, ao seu modo, trataram de diferentes maneiras e

\footnotetext{
${ }^{1}$ Neopositivismo, ou positivismo lógico, constitui um movimento filosófico definido na sua origem pelo Círculo de Viena presente na filosofia, na ciência, em instituições políticas e econômicas etc. Retoma elementos do positivismo de Augusto Comte enquanto expressão ideal do ser social burguês baseada na linguagem matemática e na quantificação da vida social; do método experimental e do empirismo lógico, tendo como critério o caráter de verdade baseado nas consequências e nas necessidades. Questiona a metafísica e a verificação das coisas está em seu conceito, cujo objetivo é encobrir o conflito entre as classes. Lukács reconheceu no Neopositivismo uma ontologia oculta, cuja base está na experiência e nas sensações, sendo que o critério privilegiado é a utilidade. O Neopositivismo suspende o ontológico e exclui da ciência questões relativas à concepção de mundo (LUKÁCS, 1988).

${ }^{2}$ A ideologia neoconservadora tende a penetrar nas instituições de maneira a controlar mediante a racionalidade tecnocrática e sistêmica, objetivando fomentar cadeias de produtividade, competitividade e de lucro, tornando o profissional mero executor de trabalhos repetitivos e burocratizados, pragmáticos e heterogêneos, não favorecendo intervenções críticas e posicionamentos ético-políticos (BARROCO, 2011).

${ }^{3}$ Diretriz filosófica que permite escolher variadas doutrinas de filósofos e aproximar-se de teses sem preocupar-se com a coerência dos ideais dessas teses entre si e de sua conectividade com suas bases originárias (ABBAGNANO, 1982).

4 De acordo com Braz e Teixeira (2009), os projetos societários têm duas características básicas, ser transformadores ou conservadores. O primeiro está voltado para transformar a sociedade e tem princípios e valores que se aliam ao projeto ético-político do Serviço Social: por sua capacidade tanto de manter determinado contexto social ou por revolucioná-lo completamente. Essa qualidade de constante transformação é o que dá uma identidade singular aos projetos societários. Aos conservadores a regra é manter estática e a mera organização social.

${ }^{5}$ No artigo A construção do projeto ético-político do Serviço Social, Netto (1999) define o novo projeto profissional da seguinte maneira: ela carrega uma imagem singular, permeada de valores que norteiam as diretrizes a serem seguida no exercício da prática profissional, dá a base para a construção de referências teóricas e metodológicas, criando normas e leis que balizam as relações sociais, seja com o público alvo, seja com outras categorias profissionais e organismos estatais e privados.
} 


\section{oreassum}

perspectivas a problemática quanto à direção hegemônica no âmbito do projeto éticopolítico do Serviço Social. O próprio José Paulo Netto vem defendendo, desde 1999, que a categoria profissional de assistentes sociais não é um bloco identitário homogêneo. Também há um consenso de que grande parte dos profissionais está enveredando para o ecletismo e o retorno ao ideário positivista - movimento este que tem ocasionado equívocos e incompreensões teóricas diante de um direcionamento social estratégico em comum.

Propomo-nos situar brevemente, no campo sócio-histórico, os principais entraves gestados no cenário pós-neoliberal ${ }^{6}$, como denomina Diniz e Boschi (2007), diante do movimento ideopolítico, econômico e cultural das transformações societárias e, principalmente, no caso brasileiro, da inércia de líderes de esquerda na implementação de reformas de base no Brasil a partir de 2003, dando continuidade à agenda do neoliberalismo. Ademais, discorreremos acerca do contexto histórico, legal e ideológico do Serviço Social brasileiro, quanto aos reflexos na estruturação e articulação do corpo político-organizativo nos projetos profissionais e societários diante de sua importância no fortalecimento das políticas públicas e da cidadania no Brasil.

A metodologia utilizada para a concretização deste estudo teórico foi a abordagem qualitativa, com caráter exploratório, e para isso, foi necessária a utilização de revisão literária. O objetivo geral é desvelar elementos que expliquem, hoje, o direcionamento social estratégico do projeto profissional do Serviço Social brasileiro, mesmo com a aderência de alguns segmentos profissionais às perspectivas pós-modernas e à descrença em metanarrativasque dão significado social à profissão. Para tanto, como objetivos específicos pretende-se: a) analisar como as teorias pós-modernas se expressam nos projetos societários e profissionais; b) discriminar o conjunto de estratégias utilizados pela categoria profissional na construção de uma direção social estratégica; e c) refletir acerca de uma contribuição expressiva do fenômeno da vontade potência7 na estruturação e articulação, seja de projetos societários ou profissionais.

Ademais, pode-se inferir que existe, hoje, no movimento da categoria profissional, expresso no conjunto das dimensões do Serviço Social brasileiro, denominado neste artigo

\footnotetext{
${ }^{6}$ A nova agenda de cunho pós-neoliberal, segundo Diniz e Boschi (2007), é entendida como a transição do governo Fernando Henrique Cardoso, na primeira década dos anos 2000, para o início do governo de Luiz Inácio Lula da Silva e sua consequente continuidade até os dias de hoje, e caracteriza-se expressivamente no grande esforço feito pelo empresariado brasileiro para reorganização da tomada do crescimento econômico, através de uma nova plataforma estratégica de desenvolvimento, utilizando o campo ético-político realizando alianças entre líderes de esquerda e de direita e as concessões para que ambos os projetos de sociedade governassem espaços nas políticas públicas setoriais brasileiras em conjunto no setor público e por meio de concessões da administração dos bens públicos dada ao setor privado.

7 Termo criado pelo filosofo alemão Friedrich Nietzsche (1985). Em sua obra Para além do Bem do bem e do mal ele defende que a Vontade de Potência seria um instinto da natureza humana que permite criar um novo ambiente, experimentar novos contextos, inverter valores e princípios, se despir da moral e inventar novos modos de vida. Tal vontade de potência seria, para o referido filósofo, insaciável, cuja força superaria os sentidos da ação teleológica do ser humano, que se manifesta no movimento das relações sociais em suas variações, de maneira que o mundo seria regido por uma força em permanente transformação, traspassando também para o campo subjetivo do pensamento humano.
} 


\section{tempordilis}

de vontade de potência ${ }^{8}$, seja na esfera formativa, da produção do conhecimento, investigativa e/ou político-organizativa, que explicita uma direção social estratégica hegemônica que reflete a significação social da profissão e que também vem sendo registrada durante seu legado sócio-histórico e maturidade intelectual da categoria profissional.

Portanto, percebe-se que estamos em tempos nefastos de reprodução sociometabólicado capital, isto é, de estrutura totalizante de organização e controle do capital, trabalho e Estado, como defende Mészáros (2011), os quais dão espaço para a ampliação das estratégias pautadas no pensamento pós-moderno, como por exemplo, o neoconservadorismo frente àcrise orgânica do capital. Tal crise orgânica ${ }^{9}$ ou de hegemonia é reflexo de desestabilização política, econômica e cultural, que só poderá se reorganizar através dos intelectuais orgânicos, assumindo progressivamente as bases do Estado, por intermédio da contra-hegemonia das classes subalternas, como aponta Oliveira (1996).

Segundo Mota (2016), essa crise está abrindo margem para o retorno de poderes políticoeconômicos, patriarcais, patrimonialistas e de segregação das classes sociais, alimentada pela agenda do projeto societal burguês de cunho antidemocrático, configurando diversos retrocessos contemporâneos no âmbito de políticas públicas setoriais nas áreas de saúde, da assistência social, do trabalho, da previdência social, de educação e/ou meio ambiente. Mesmo assim, diante dos avanços das investidas neoliberais é possível identificar vitórias da direção ético-política estratégica da categoria do Serviço Social e de projetos societários convergentes.

Quanto à estrutura organizativa do artigo, este contém três tópicos: o primeiro, refere-se aos desafios postos pelo pensamento pós-moderno no âmbito dos projetos profissionais e societários; no segundo, a ênfase é na argumentação das possibilidades de um Serviço Social mais encorpado profissionalmente e mais robusto na produção intelectual e política no Brasil de hoje; o terceiro está focado no entendimento de que há um esforço na implementação dos objetivos estratégicos para materialização do projeto profissional do Serviço Social. Nas considerações finais, espera-se proporcionar ao leitor um melhor entendimento dos processos de resistências às investidas do modelo político-econômico vigente.

\footnotetext{
${ }^{8}$ Neste artigo, defende-se que há um movimento de vontade de potência que permeia o projeto profissional do Serviço Social no conjunto das dimensões profissionais. Entretanto, tal fenômeno é diferente da concepção conceitual desenvolvida pelo filosofo Nietzsche (1975), na qual é aqui entendido como a coragem de lutar constantemente, sendo o elemento constitutivo dessa vontade de potência a capacidade para pensar, criar, produzir, agir e executar a direção social estratégica partindo da intencionalidade do pensamento teleológico à produção concreta de um resultado histórico e social.

${ }^{9}$ A crise orgânica ou crise da hegemonia é caracterizada pela desestabilização da ordem política, cultural e econômica. Nessa situação, o poder do Estado se enfraquece e as classes subalternas, organizadas através de seus intelectuais, criam condições para preparar as bases da contra-hegemonia e progressivamente assumir o controle do Estado (OLIVEIRA, 1996).
} 


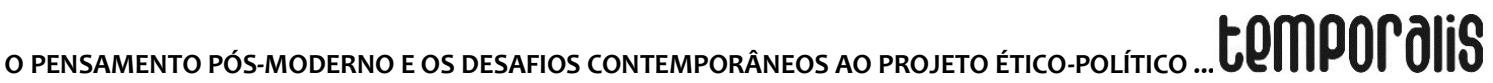

\title{
O PENSAMENTO PÓS-MODERNO E AS FISSURAS NOS PROJETOS SOCIETÁRIOS E PROFISSIONAIS NO BRASIL DE HOJE
}

Qual o impacto, hoje, do pós-modernismo no movimento ideológico, político e teórico no âmbito do projeto profissional do Serviço Social? Ademais, quais os rebatimentos na direção sociopolítica do projeto profissional do Serviço Social e na apropriação deste rumo à viabilização de um novo projeto de sociedade?

Diante de tais questionamentos, diversos estudiosos da temática começaram a registrar a intenção da construção do projeto profissional desde os fins da década de 1970, (NETO, 1996; MOTA, 2007; MOTA; AMARAL, 2009; BRAZ; TEIXEIRA, 2009). Porém, é no final do século $\mathrm{XX}$ que esse posicionamento fica mais claro e objetivo quanto ao direcionamento da categoria dos assistentes sociais, inclusive com a reformulação dos marcos regulatórios, em 1993, do Código de Ética Profissional, da Lei de Regulamentação da profissão (Lei n ${ }^{\circ}$ 8.662/93) e das novas Diretrizes Curriculares para o Curso de Serviço Social, especialmente no que se refere à inserção de novos conteúdos ao currículo acadêmico, recomendada pela Associação Brasileira de Ensino e Pesquisa em Serviço Social (ABEPSS) $\left(1996^{10}, 1999^{11}\right.$ e $2002^{12}$ ). Historicamente, esses marcos têm se configurado como pressupostos para o delineamento dos princípios, objetivos e estratégias da construção permanente do projeto Ético-Político do Serviço Social ou do novo projeto profissional, como o batizou Netto (1999).

Mesmo diante de avanços quanto à estruturação e articulação dos profissionais que compõem o projeto profissional no contexto histórico brasileiro, não podemos nos esquecer do caráter contraditório deste com relação aos objetivos do projeto de sociedade vigente, ou seja, do capitalismo e de seu sistema filosófico, político e econômico. O neoliberalismo, doutrina segundo a qual se apropria da defesa de liberdade de mercado às exigências da sociedade de consumo. Tal modelo tem conquistado, historicamente, um número crescente de consumidores ao mesmo tempo em que oferece e difunde uma visão conservadora de sistema social, na perspectiva de desarticular e fragmentar os movimentos sociais e frações de classe que atuam numa direção hegemônica na construção tanto de um novo projeto de sociedade quanto de projetos profissionais. De acordo com Oliveira (1996):

\begin{abstract}
Enquanto dominação e direção, a hegemonia assegura a uma determinada classe certo poder, mas ao mesmo tempo expressa o caráter democrático. Gramsci identifica explicitamente a noção de hegemonia à democracia como relação orgânica entre dirigentes e dirigidos. É a partir do conceito de hegemonia e da função que os intelectuais desempenham nos aparelhos de hegemonia, que, progressivamente, Gramsci amplia o seu conceito de Estado (OLIVEIRA, 1996, p. 63).
\end{abstract}

Por ser o neoliberalismo um sistema influenciado, na ordem política, por várias correntes, reafirma os critérios de segurança e o reforço das garantias públicas. Nesse sentido, é

\footnotetext{
${ }^{10}$ Para mais informações consultar Associação Brasileira de Ensino e Pesquisa em Serviço Social (1996).

${ }^{11}$ Para mais informações consultar: Brasil (1999).

${ }^{12}$ Para mais informações consultar: Brasil (2002.
} 


\title{
temporalis
}

possível diferenciar, historicamente, no Brasil, uma diversidade de posicionamentos éticopolíticos tanto no que se refere à ampliação da democracia quanto ao alargamento da emancipação política de frações das classes subalternas que, juntas, caminham trilhando nos rumos da emancipação humana, na perspectiva de projetos alternativos à sociedade do capital.

Nesse contexto, grande parte dos profissionais do Serviço Social, unida pela categoria trabalho, tem sentido as sequelas de tais ofensivas, como nos afirma Mota e Amaral:

\begin{abstract}
As transformações societárias em curso, expressão da crise capitalista e dos mecanismos associados pelas classes dominantes para o seu enfrentamento atingem frontalmente a relação entre o Estado e a sociedade, seja pela hipoteca à mediação do mercado como instância que regula a vida social (ideologia neoliberal), seja pela emergência de ideologias que justificam o apagamento dos antagonismos de classe (ideologia pós-moderna), ou ainda, pela adoção de estratégias e táticas dos governos das classes dominantes que sitiam os projetos alternativos à sociedade do capital (MOTA; AMARAL, 2009, p. 51).
\end{abstract}

A magnitude de tais desafios, diante de transformações societárias nas relações sociais, reflete em dificuldades tanto nos projetos societários, ou macroscópicos, quanto nos profissionais, ou microscópicos (NETTO 1999), ou seja, na idealização e materialização do novo projeto profissional do Serviço Social. Tais desafios se expressam basicamente em três dimensões: no processo de produção do conhecimento, na luta pela manutenção da direção ético-política norteada pelos marcos legais e institucionais e também nas estratégias de organização política da categoria (RAMOS, 2009).

É a partir desta concepção de sitiar projetos alternativos que percebe-se mais claramente, no campo da ideologia pós-moderna, a influência de um pensamento distanciado de uma razão historicamente construída, que se alimenta de uma idealização arbitrária, da fuga da compreensão real do mundo, o que pode em um primeiro momento aparentar ser bastante libertador e criador, todavia, em sua essência, seria apenas uma idealização da razão subjetiva esvaziada de significado de uma verdade concretamente construída.

Por conseguinte, é mediante a complexidade das relações sociais que tais transformações societárias são registradas de duas maneiras: primeiramente, na tentativa da desarticulação de movimentos sociais independente da atuação dos campos dos movimentos tradicionais ou dos novos movimentos sociais e também entre as categorias profissionais quanto à construção de qualquer projeto macrossocietário ou microssocietário; em segundo, pela tentativa de desacreditar as teorias que dão significado sócio-histórico aos projetos societários e "[...] direção sociopolítica no processo de ruptura com o conservadorismo [...]" (ABRAMIDES, 2006, p. 71) de cunho marxista que norteia hegemonicamente o projeto ético-político do Serviço Social. Ambos os movimentos refletem negativamente no campo interventivo, seja das classes sociais, na relação entre sociedade e Estado na luta por direitos sociais, seja da profissão do Serviço Social na implementação do ideário de construção de estratégias rumo a uma nova ordem societária, colocando-a muitas vezes no campo do ecletismo, pragmatismo e/ou 


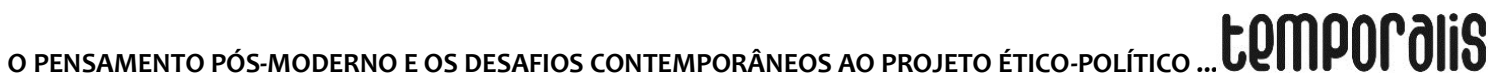

tecnicismo, a partir do reaparecimento de uma reação neoconservadora ${ }^{13}$ explícita ou disfarçada em sua real aparência, revelando que estes movimentos são constitutivos de tendências pós-modernas e/ou de outras perspectivas teóricas que solapam a negação no entendimento de processos históricos numa dimensão de totalidade e anulam qualquer antagonismo da luta de classes sociais, dando um caráter vazio de conteúdo sóciohistórico, ético-político e técnico-interventivo (IAMAMOTO, 2015).

Tais fenômenos considerados constitutivos da contrarreforma do Estado democrático ou do movimento de contracultura, principalmente a partir da década de 1970, em escala global, também marcaram o campo da arte, entendido nesse contexto como cultura que explora e dá sentido diverso às expressões e significados das relações sociais. Tal cultura não estaria imune à influência da estética nas perspectivas pós-modernas (no decorrer de seu desenvolvimento sócio-histórico) e das mudanças significativas na apropriação dos modos de vida, e de que esta viesse a incorporar características singulares que dessem um novo significado às suas expressões artísticas, imprimindo-a agora de maneira descontextualizada no tempo e infinita em sua subjetivação interpretativa, distanciandose de princípios morais abarcados pela ética. Diante disso, Harvey (1992, p. 295), constatou que estávamos passando por um tempo em que estava claro que "[...] o triunfo da estética sobre a ética não podia ser mais evidente” (HARVEY, 1992, p. 295).

Atualmente, a ideologia pós-moderna perpassa várias dimensões. No campo dos novos movimentos sociais, especificamente na área do movimento ambiental, o Greenpeace ${ }^{14}$ tem demonstrado em suas manifestações um ofuscamento no que se refere à proposta de uma nova ordem societária e o combate a perspectivas de manutenção do capitalismo através da implementação das estratégias do desenvolvimento sustentável, limitando-se a se satisfazer com pequenas concessões impostas às empresas - nacionais ou multinacionais, aderindo a determinações de organizações internacionais nas metas somente para diminuição da emissão de $\mathrm{CO}^{2}$ (Política de crédito de carbono) ${ }^{15}$. A adesão a

\footnotetext{
${ }^{13} \mathrm{O}$ conservadorismo é uma ideologia emergente da crise do capital, que se alimenta da ideia de que a única alternativa para a manutenção do capitalismo é sua conservação tanto na esfera intelectiva quanto institucional, cuja mesma tem uma posição basilar no que se refere às contradições do Serviço Social, resultando em entraves no exercício profissional e no processo de amadurecimento da dimensão da produção do conhecimento. O interessante é que só recentemente, entre os anos 1990 e 2000, têm-se percebido duas tendências de estudos que estão dando suporte à formação de uma massa crítica no interior do Serviço Social, são elas: estudos que abordam o “neoconservadorismo pós-moderno", e também, os que priorizam o conservadorismo clássico, que floresce como discurso antirrevolucionário no período da revolução francesa, permitindo uma ampliação do debate acerca dessas temáticas (SOUZA, 2016).

${ }^{14}$ Organização não governamental (ONG) mundial criada em 1971, cuja finalidade é a luta pela preservação de determinados recursos naturais, de espécies de animais ou vegetações específicas de determinada região. Para mais informações acessar: <http://www.greenpeace.org>.

${ }^{15} \mathrm{O}$ Crédito de Carbono ou Redução Certificada de Emissões (RCE) são certificados emitidos para uma pessoa ou empresa que reduziu a sua emissão de Gases do Efeito Estufa (GEE), proporcionando isenções fiscais. Historicamente, a humanidade tem optado em apostar em ações resolutivas imediatas e de curto prazo no âmbito da governança ambiental global, as quais apenas amenizam a problemática socioambiental. Como exemplo disso, temos a economia verde de baixo carbono para redução da emissão dos Gases do Efeito Estufa. Todavia, tal comportamento não consegue resolver efetiva e eficazmente a questão da poluição e revela, desde as propostas lançadas na Rio+20, a sua obsolescência, gerando bloqueios à governança ambiental. Com isso, dá-se margem para a implementação de modelos conservadores (Estados Unidos e China) e soberanistas (União Europeia), estes alinhados ao sistema das Nações Unidas e das diretrizes do G-
} 


\section{temporalis}

essa política por si só não elimina a poluição do meio ambiente nem, tampouco, com intervenções pontuais de preservação conservacionistas de determinada espécie de animal, fauna e/ou flora, esquecendo-se da articulação com uma perspectiva de totalidade no enfrentamento da questão socioambiental. Tais fenômenos observados, de natureza conservacionista e reducionista nos movimentos ambientais podem evidenciar uma influência de tendências e concepções pós-modernas como norteadoras dos referidos movimentos.

Referente à influência das lutas da classe trabalhadora brasileira, esta contribuiu para a criação das primeiras instituições que ofereciam garantias mínimas ao trabalhador. $\mathrm{Na}$ implementação das políticas públicas setoriais, diferente do contexto sócio-histórico da Política de Saúde na estruturação do Sistema Único de Saúde (SUS), que teve a ampla participação da sociedade civil, a construção e estruturação da Política de Assistência Social no Brasil, deveras teve grande apoio de categorias profissionais, em particular de assistentes sociais, mas parca participação democrática da sociedade civil. Certamente, por esta parcela das classes populares ter sido considerada afetada, ao longo da formação sócio-histórica brasileira, pelo processo de cidadania inconclusa, o que sempre predominou foram as relações assistencialistas e paternalistas no Brasil. A Política de Assistência Social ainda é compreendida por aqueles que dela necessitam, não como direito, mas como uma política onde predomina o favoritismo, o clientelismo e a benemerência. Esses sujeitos são destituídos tanto de sua própria identidade quanto de acesso a bens e serviços como sujeitos de direitos no exercício de cidadania (CFESS, 2011).

Ademais, segundo Harvey (1992), é a partir da década de 1970 que ocorrem transformações significativas no âmbito temporal e espacial que põe os movimentos e os princípios norteadores da cultura em xeque pelo avanço do pensamento pós-moderno, na medida em que gera a dúvida sobre postulados, juízos científicos e morais regidos por princípios e valores éticos, dando lugar a uma onda de glorificação da estética que se afastava de metanarrativas ${ }^{16}$ pautadas em uma realidade concreta, prevalecendo o espírito efêmero e uma individualidade que alimentava a fragmentação e o estímulo a práticas culturais autônomas em detrimento de discursos sobre verdades construídas historicamente, de direcionamentos éticos e políticos ou de fundamentos materiais e econômicos, que tem sido utilizada como estratégia do capital, pois

[...] das crises de superacumulação catalisar a busca de soluções temporais e espaciais que criam, por sua vez, um sentido avassalador de compressão do

20 que, mesmo trabalhando em conjunto, tornam-se incapazes de dar respostas eficazes aos problemas socioambientais contemporâneos. O Brasil é diretamente afetado na medida em que aplica esse modelo de governança ambiental, de estímulo à economia verde de baixo carbono visando o desenvolvimento sustentável (relação produção-consumo), ao colocar em risco o estoque de carbono florestal brasileiro, considerado o maior do mundo (VIOLA; FANCHINI, 2012).

16 Basicamente, resulta de teorias construídas sócio-historicamente e que, em certa medida, são universalmente conhecidas, disseminadas e seguidas, são pautadas por princípios e valores de uma razão construída seja pela ciência ou do desenvolvimento da construção do conhecimento na era moderna, a qual pode dar subsídios para que os seres humanos se oponham ao senso comum, às fábulas, aos mitos, superstições religiosas ou abstrações da subjetividade humana, a qual temos como exemplo, no caso do Serviço Social, uma forte tendência dos postulados da metanarrativa criada pelo pensador Karl Marx e/ou do pensamento neomarxista. 


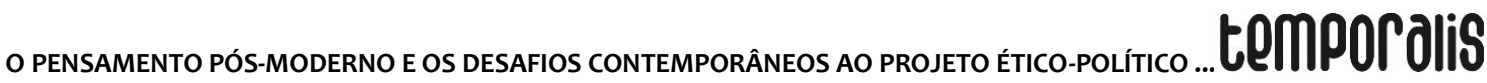

tempo-espaço, também podemos esperar que as crises de superacumulação sejam seguidas por fortes movimentos estéticos. [...] A experiência do tempo e do espaço se transformou, a confiança na associação entre juízos científicos e morais ruiu, a estética triunfou sobre a ética como foco primário de preocupação intelectual e social, as imagens dominaram as narrativas, a efemeridade e a fragmentação assumiram precedência sobre verdades eternas e sobre a política unificada e as explicações deixaram o âmbito dos fundamentos materiais e político-econômicos e passaram para a consideração de práticas políticas e culturais autônomas (HARVEY, 1992, p. 291).

É notório que não só na trajetória histórica da profissão, mas englobando as demandas dos projetos societários dos trabalhadores e demais, passamos principalmente pelas décadas de 1980 e 1990 em constante confronto, opondo-se às investidas das classes dominantes por intermédio de suas estratégias neoliberais, alimentado pelo estímulo de financeirização do capital (BRAZ, 2007). Da mesma forma, a partir dos anos 2000, tem-se no campo econômico, pelo processo de desnacionalização dos bens públicos, a implementação da agenda pós-neoliberal, de acordo com Diniz e Boschi (2007). Essa tendência se agravou com as alianças políticas realizadas entre a esquerda e a direita brasileira, afetando as bases do Estado democrático de políticas públicas e gerando uma desarticulação da sociedade civil e da categoria trabalho na luta por direitos sociais (MOTA, 2010).

Todavia, segundo Netto (2007), o neoconservadorismo $0^{17}$ inserido e aliado às estratégias pós-neoliberais tem colocado em descrédito a articulação e organização de movimentos tradicionais relacionados à classe que tem no trabalho seu sustento, sendo exemplos concretos os movimentos sociais como a CUT (Central Única dos Trabalhadores), UNE (União Nacional dos Estudantes), MST (Movimento dos Trabalhadores Rurais Sem Terra) e outros, os quais têm atualmente aderido às perspectivas pós-modernas que corroboram para legitimar e ao mesmo tempo manter o sistema político-econômico vigente, o vertiginoso capitalismo, aderindo à política de conciliação de classes sociais.

Para além da perspectiva neoconservadora, é necessário entendermos melhor o que de fato vem a ser o movimento das teorias pós-modernas, visão hegemônica e uma das responsáveis pelas transformações societárias. Essa visão se caracteriza por priorizar incessantemente o tempo presente (o agora), desconsiderando a historicidade humana, prevalecendo a efemeridade, a idealização dos sentimentos e o espírito individualista. Também incorpora a subjetividade e a concepção de que deve desenvolver-se alheio à ciência, opondo-se a qualquer crítica ou pensamento que contemple o conceito de totalidade ou realidade complexa.

Nessa perspectiva, o pensamento pós-moderno é baseado em um traço marcante e estruturador, definindo-se pela sua necessidade de fragmentação, seja pelas classes

\footnotetext{
17 Para Netto (2016) o neoconservadorismo, derivado de posturas pós-modernas, se constitui hoje em ferramenta de erosão do projeto profissional do Serviço Social na medida em que exalta suas concepções e intervenções estritamente práticas, pondo em xeque os ideais do referido projeto profissional. Consequentemente, uma não reação à influência neoconservadora, apropriada pelo pensamento pósmoderno, e sua tendência resiliente na qual se apoia, pode ocasionar uma inflexão na direção sociopolítica da profissão, instaurando o retorno ao Serviço Social tradicional da década de 1930 no Brasil.
} 


\title{
temporalis
}

sociais, movimentos sociais ou por qualquer organização da sociedade em prol de legitimação ética, moral ou identitária, o que deixa explícito que este se faz na máxima de que a verdade é que não existe verdade absoluta, permitindo-o explorar sem medida o campo da abstração, dando lugar e vez à interpretação de maneira singular do indivíduo em detrimento ao entendimento da coletividade (HARVEY, 1992).

Se considerarmos como hipótese central que essa máxima se expressa como o resultado do não reconhecimento sócio-histórico das lutas coletivas travadas no campo dos projetos societários, então ela é a responsável primeira pela fragmentação da luta coletiva da classe trabalhadora, seja no passado, seja no presente e/ou das que possam vir a se constituir no futuro em seu sentido valorativo. Portanto, podemos dizer que no campo ideológico "[...] não há dúvidas de que o capitalismo contemporâneo, em sua fase destrutiva, atua com força brutal em seu projeto de contrarreforma" (RAMOS, 2009, p. 45).

Em contra partida, existe na essência das teorias pós-modernas um elemento contraditório: o fato de considerar a não existência de verdades absolutas. Se o pensamento pós-moderno for ter como legítimo tal afirmação, é provável que este coloque em xeque seu legado e seja ofensivo tanto à natureza humana quanto a si, já que poderia ser facilmente desconstruído pelos mesmos que o criaram, já que tem se apoiado na premissa fundante da razão subjetiva (JAMESON, 1996).Tal afirmação é explicada também por Harvey da seguinte maneira:

\begin{abstract}
O Pós-modernismo ${ }^{18}$ surgiu em meio a este clima de economia vodu, de construção e de exibição de imagens políticas e de uma nova forma de classe social. A existência de alguns vínculos entre essa eclosão pós-moderna, a construção de imagens de Ronald Reagan, a tentativa de desconstruir instituições tradicionais de poder da classe trabalhadora (os sindicatos e os partidos de esquerda) e o mascaramento dos efeitos sociais da política econômica de privilégios deveria ser bastante evidente. Uma retórica que justifica a falta de moradias, o desemprego, o empobrecimento crescente, a perda de poder etc. apelando a valores supostamente tradicionais de autoconfiança e capacidade de empreender também vai saudar com a mesma liberdade a passagem da ética para a estética como sistema de valores dominante (HARVEY, 1992, p. 301).
\end{abstract}

Com isso, o movimento pós-modernista nos remete a um lugar de instabilidade e insegurança. Coloca-nos no meio da desordem das ideias concretas, sem visões delimitadas, constituído essencialmente através de interpretações da subjetividade humana em sua permanente mutação, estando hoje na contramão da viabilização do atendimento às demandas de projetos profissionais e de sua articulação aos ideais de projetos societários democráticos. Com isso, promove o processo de individualização das lutas, desarticulação das categorias sociais coletivas, fragmentando o processo

\footnotetext{
${ }^{18}$ Em 2002, o professor José Paula Netto, ministrando sua aula inaugural do Programa de Estudos de PósGraduação em Serviço Social da PUC-SP, intitulada Pós-modernidade: gênese, significado histórico e traços constitutivos, reconhece o pós-modernismo como uma ideologia, com suas multiformas, expressados em fatos, derivados da causalidade de um sistema em movimento resultante de uma historicidade da ação humana, onde os fenômenos encontram sua implicação, expressam-se e permitem uma linha de raciocínio coerente que os expliquem.
} 


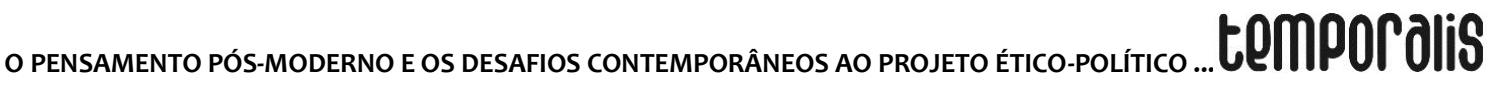

organizativo de classes sociais na luta pela efetivação dos direitos sociais, de ampliação do acesso a bens e serviços e do exercício da cidadania.

O que se vivencia na arte contemporânea é uma era dos símbolos, se sobrepondo às expressões ideológicas e culturais, onde a representação de determinada obra pode serexclusivamente idealizada de forma tal que não precisaria mais ter referência de começo, meio e fim, sendo interpretada unilateralmente e ao gosto do observador. Segundo Ternas:

Com a ascendência do Espírito pós-moderno, a busca do Homem por um significado no Cosmo passou para um empreendimento hermenêutico com uma flutuação desorientadoramente livre: o ser humano pós-moderno existe num Universo cujo significado está ao mesmo tempo inteiramente em aberto e sem nenhuma fundamentação teórica (2008, p. 425).

Porquanto, podemos levantar a premissa de que mesmo que seja no campo social, político, econômico ou cultural, a subjetividade tende a alimentar a criatividade. Isso, em parte, é bom, mas também fomenta nesse processo o ego e a expectativa individual no campo da linguagem conotativa, elementos que, juntos, não favorecem para a construção de referenciais histórico-sociais. Com isso, o pensamento pós-moderno se perde no tempo ao se esquecer de contemplar e de reavivar que vivemos no campo da linguagem denotativa, nos limites de uma totalidade da dimensão sócio-histórica, ligados a um bloco histórico e que é isso que dá sentido e significado social aos projetos profissionais e societários.

Tal premissa afirmativa nos remeteria a um verdadeiro jogo de espelhos, como se tal sociedade pós-moderna não precisasse mais recorrer à relação entre sociedade e natureza, ou até mesmo esquecer os referenciais construídos mediante o tempo e espaço, elementos estes que dão significado ao movimento das relações sociais e às projeções teleológicas do futuro através da interpretação e valorização do passado (HARVEY, 1992).

Atualmente, esse conjunto de elementos abarcados pelas teorias pós-modernas são, na visão de Braz (2007), o que corrobora que este levante dois argumentos em defesa da ideia de uma crise de hegemonia ${ }^{19}$ do projeto ético-político profissional: o primeiro, baseia-se no argumento de que a categoria é desprovida de estratégias para uma superação do sistema capitalista brasileiro, não tendo capacidade, até o presente momento, para unificar interesses sociais relacionados aos projetos societários diante da diversidade de projetos da classe trabalhadora e disputa entre este e a classe dominante; o segundo está relacionado à massificação da formação e às condições materiais, ou seja, da mercantilização do ensino superior e da precarização das condições objetivas de trabalho para realização do exercício profissional. Entretanto, há entendimentos diversos e até opostos acerca da afirmativa do autor citado acima sobre um possível descrédito na

\footnotetext{
19 Para Buci-Glucksmann (1980, p. 83), não pode haver teoria da hegemonia sem teoria da crise da hegemonia (dita crise orgânica); não há análise da integração das classes subordinadas a determinada classe dominante, sem teoria dos modos de autonomização e de constituição de classes que permitem a uma classe antes subordinada tornar-se hegemônica; não há extensão do Estado sem redefinição de uma perspectiva estratégica nova: 'a guerra de posição', que permita a classe operária lutar por um novo Estado.
} 
hegemonia ${ }^{20}$ do projeto ético-político profissional do Serviço Social, onde Ramos (2009) afirma que

[...] não temos, na conjuntura atual, elementos concretos para concluir que existe uma crise de hegemonia do projeto ético-político do Serviço Social, pois nas suas três esferas constitutivas não há indicativos para tal. Do ponto de vista da produção do conhecimento, notamos que a predominância da teoria social crítica nas nossas produções permanece. É só olharmos, por exemplo, a biblioteca básica da Cortez, todos numa direção de afirmação do nosso projeto; se analisarmos, também, os materiais do curso do CFESS/ABEPSS e CEAD/UNB, [...] percebemos que a direção social está mantida neste âmbito da produção de conhecimento. [...] No âmbito dos nossos instrumentos normativos não identifico elementos para falar de crise de hegemonia. [...] E na dimensão da organização política, penso, também, que mantemos, na multiplicidade das entidades representativas nacionais [...] uma direção política de sustentação ao projeto profissional hegemônico (RAMOS, 2009, p. 47).

A partir do exposto, pode-se concluir que não se deve descartar, por completo, que tais elementos ressaltados por Braz (2007) não podem vir a trazer desafios para o projeto profissional do Serviço Social, corroborando para uma possível inviabilização na concretização da implementação do direcionamento ético-político da Profissão e/ou fissuras na articulação com projetos de sociedade que vislumbre um ideal de emancipação política para além dos moldes estabelecidos pelo capitalismo na busca da almejada emancipação humana. Todavia, o que se pode deixar marcado é que há argumentações de que o movimento hegemônico que tem se processado no interior da categoria vem contribuindo para que esta amplie seu horizonte e realize modificações éticas e políticas, tanto no âmbito de sua prática interventiva quanto na luta pela ruptura com as correntes neoconservadoras.

Para tanto, é preciso estar atento quanto às possíveis estratégias de contrarreforma frente à ideia de crise de hegemonia no direcionamento social do projeto profissional, o que não quer dizer que a categoria que tem como bandeira de luta tal projeto, na afirmação de sua direção social, tenda a se afastar ou a desacreditar que a natureza deste esteja em decadência; pelo contrário, tem-se presenciado um movimento de resistência ao conjunto das teorias neoconservadoras constitutivas do pensamento pós-moderno em suas várias frentes aos processos de dilapidação, tanto do novo projeto profissional, ainda em construção, quanto à sua articulação com projetos societários que caminhem em paralelo.

\section{A VONTADE DE POTÊNCIA MATERIALIZADA NO PROJETO ÉTICO-POLÍTICO PROFISSIONAL}

É justamente o fato de termos referenciais teórico-metodológicos definidos, uma identidade estabelecida, pautada em uma metanarrativa e de uma capacidade éticopolítica de reavaliação e de autoavaliação permanente, que levantamos a hipótese de que

\footnotetext{
${ }^{20}$ Segundo Gruppi (1980), a hegemonia se expressa na capacidade de unificar por meio da ideologia e de manter unido um bloco social que não é homogêneo, sendo marcada por profundas contradições de classe. Uma classe é considerada hegemônica, dirigente e dominante, na medida em que, por meio da ação política, ideológica e cultural mantém um grupo de forças heterogêneas e conseguindo impedir a divergência existente entre tais forças. Sem essa unidade hegemônica, pode provocar uma crise na ideologia dominante, que leva à recusa de tal ideologia, fato que irá coincidir com a crise política das forças no poder.
} 


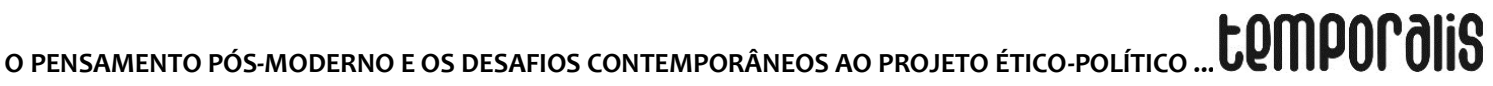

estamos utilizando de forma construtiva o que aqui denominamos de vontade de potência. Esta se configuracomo elemento constitutivo do movimento de intenção de ruptura que o projeto profissional da categoria se propõe com o conservadorismo e o neoconservadorismo no ato de se desvencilhar de ranços de teorias de base neotomista, neopositivista e estrutural-funcionalista, bem como o elemento impulsionador no projetar teleologicamente a luta para a concretização de uma nova ordem societária, imprimindo um significado soció-histórico e político que ainda nos põe em movimento.

O interessante em destacarmos esse movimento causado pelo fenômeno da vontade de potência no âmbito do Serviço Social, atualmente, é que este tem se expressado não somente em uma área específica, mas em todas as dimensões em que o Serviço Social se expressa na sociedade, tornando-se uma arma necessária e estrategicamente urgente em momentos de afirmação da direção social estratégica que tem lutado contra três elementos definidores do pensamento pós-moderno. Primeiro, parte de uma realidade baseada meramente nas representações construídas pela racionalidade cognitiva, sendo a verdade mero produto interpretativo; Segundo, a natureza da emancipação humana é vista como utópica, prevalecendo uma visão reguladora da sociedade, ou seja, a razão é esvaziada de conteúdo sócio-político; e, por último, a verdade é construída pelo consenso do aparente e do discursivo - aqui a categoria chave é pactuação, bastando o consenso do senso comum em meio a um conjunto de histórias ou montante de verdades contadas para, e somente para, estabelecer verdade interpretativa ou discursiva, desvinculada de práticas tradicionais ou científicas.

Tais elementos têm, de forma indireta, repercutido negativamente na estruturação dos projetos profissionais. Por isso é importante refletir acerca das possibilidades de um Serviço Social mais encorpado profissionalmente e mais robusto na produção intelectual no Brasil de hoje, sabendo que é legítimo e até saudável, para clarear o caminho no qual estamos a seguir de fato, nos basearmos no discurso argumentativo e da arte do convencimento que, por meio da razão científica e teórica, forma verdades no seio da sociedade moderna hoje,mediante a concepção de totalidade de ideias, de imagens, de representações e interpretações da realidade concreta.

Por isso, é importante sabermos que antes de qualquer ação, para a efetivação de determinado projeto, seja ele de sociedade ou pertencente a um seguimento de classe social ou de determinada categoria profissional, este deve ter um rumo traçado (uma filosofia política), como também o mesmo não deve depender somente do campo da vontade, mas principalmente de um método e um planejamento que permita viabilizar sua concretização diante da sociedade através do que denominamos, neste artigo, vontade de potência. No caso do projeto profissional do Serviço Social, está posto que, durante seu processo de construção, este sempre buscou a recusa de perspectivas que venham estimular a reprodução de práticas de tendências conservadoras e distanciada do conjunto da análise da sociedade em sua totalidade histórico-social.

Tal distanciamento reflete um posicionamento contemporâneo importante no campo ético-profissional. Significa dizer que a ética expressa o ato de refletir criticamente sobre determinada conduta e que a mesma é dependente de duas tomadas de posição importantes para a formação do ethos profissional do Serviço Social: de um lado, o(a) 


\section{temporalis}

assistente social deverá levar em consideração os princípios éticos orientadores explícitos no Código de Ética de 1993, considerando os argumentos teleológicos, éticos e políticos; por outro lado, deverá tomar como referência o cotidiano profissional, o respeito e o cumprimento das normativas legais e o respeito aos posicionamentos dos profissionais. Estas dimensões que desenham o ethos profissional, segundo Cardoso e Torres (2016), devem ser interpretadas como uma dimensão específica, na medida em que o

[...] projeto profissional e ética profissional não são sinônimos, bem como não podemos reduzir a ética profissional ao código de ética, tratando-se de uma compreensão mais ampla de uma práxis que envolve valores, ações e instrumentos jurídicos que constituem um ethos (modo de ser) profissional. [...] Podemos afirmar que temos a presença de duas perspectivas éticas no seio do Serviço Social que foram sendo construídas historicamente na profissão, as quais cremos estarem presentes até os dias atuais [...] de uma ética tradicional/conservadora e uma ética de ruptura/emancipatória (CARDOSO; TORRES, 2016, p. 185-186).

Também, não podemos esquecer que existem algumas características basilares no âmbito dos projetos societários e profissionais que, segundo Netto (1999), Ihes dão a capacidade de movimento, quais sejam: 1) ser mutável; 2) possibilidade de transformação de sua base ideológica; 3) reconstituição do direcionamento ético-político e cultural; e 4) são cambiantes, isto é, podem trocar de objetivos e prioridades nos processos de organização de lutas ou de suas projeções profissionais dependendo do contexto social, histórico, político ou econômico.

Nesse contexto, tal capacidade de renovação permite, por um lado, uma abertura para revisão de suas referências teórico-metodológicas, do direcionamento político e ético e de sua estruturação quanto às ações prático-interventivas diante da finalidade de atender aos interesses propostos pelas classes sociais. Por outro lado, é nessa seara da capacidade dinâmica de mutação, autocrítica e de permanente reconstrução que as teorias pósmodernas encontram um chão fértil para imprimir modos de vida em sociedade e, consequentemente, influenciar de maneira diversa e, por que não, nefasta, na tentativa de deterioração de princípios éticos, desestabilização de forças políticas, de desordem da base de organização coletiva, da sobreposição do cotidiano sob a cientificidade, do exercício profissional e/ou na maneira de conduzir as práticas interventivas no âmbito das profissões.

Por conseguinte, se formos nos reportar à análise do projeto profissional do Serviço Social na atualidade, lamamoto (2015) nos alerta para uma dupla armadilha que pode trazer consequências nefastas ao processo de implementação e ampliação deste. Todavia, também elenca estratégias para o enfrentamento de tais desafios da agenda neoliberal contemporânea, rebatendo inclusive a teoria defendida por Braz (2007) da já instalada crise da hegemonia no Serviço Social, na medida em que expõe como importante que

Para atribuir densidade histórica ao projeto profissional, é necessário identificar as forças sociais reais que polarizam os projetos societários no país [...] aprofundar a leitura social na atualidade para estabelecer uma base realista - sem perder o encanto do sonho e da utopia - às nossas projeções profissionais e à sua viabilização. Sem considerar essa dinâmica histórica, ao se falar em projetos societário e profissional pode-se cair na armadilha de um discurso que proclama 


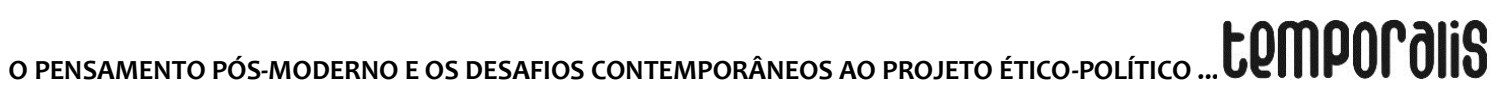

valores radicalmente humanistas, mas não é capaz de elucidar as bases concretas de sua objetivação histórica. Essa artimanha pode subverter a projetada intencionalidade progressista, correndo-se o risco de reforçar e atualizar uma dupla armadilha persistente na história do Serviço Social: de um lado, atualizar a clássica disjunção entre valores e conhecimento, que afirma a apreciação moral das injustiças, mas, no campo do conhecimento, não é capaz de desvendar os processos históricos [...]. De outro lado, o risco de repor objetivos finalistas dissociados da dinâmica conjuntural e dos sujeitos que the dão sustentação histórica: a 'missão' nos primórdios do Serviço Social, a consigna da transformação social, tal como empregada no movimento de reconceituação do Serviço Social e reciclada como Serviço Social alternativo no contexto latino-americano da profissão (IAMAMOTO, 2015, p. 228-229).

Para além dos entraves supracitados, também como exemplo pode-se citar o reconhecimento do pluralismo (permite numa mesma categoria profissional, referenciais teórico-metodológicos distintos) que em certa medida permite o debate diante da autocrítica e a refutação das diversas teorias de tendência neoconservadora do pensamento pós-moderno no corpo da categoria profissional, convergindo para uma unidade de diversos e, por outro lado, instaura o caráter contraditório deste diante dos distintos interesses entre as classes sociais no interior dos projetos profissionais ou mesmo dos societários, até porque sua natureza de fato já se apresenta limitada na medida em que os projetos, por não conseguirem ser em sua totalidade hegemônicos, mesmo que estes caminhem com a maioria para tal proposta em comum, podem ocorrer em determinadas situações conflitos, fissuras e contradição interna. A partir desse caráter contraditório, na atuação de várias vertentes, compondo o movimento do Serviço Social brasileiro, é o que pode vir a gerar a complexidade quanto a sua concepção e direção hegemônica, influenciando expressivamente positiva ou negativamente a direção social e política do referido projeto.

De acordo com Netto:

O corpo profissional é uma unidade não hegemônica, uma unidade de diversos; nele estão presentes projetos profissionais e societários diversos e, portanto, configura um espaço plural do qual podem surgir projetos profissionais diferentes. Todo corpo profissional é um campo de tensões e de lutas. [...] A afirmação e consolidação de um projeto profissional em seu próprio interior não suprime divergências e contradições. Tal deve fazer-se mediante o debate, a discussão, a persuasão - enfim, pelo confronto de ideias que e não mecanismos coercitivos e excludentes. Contudo, sempre existirão segmentos profissionais que proporão projetos alternativos; por consequência, mesmo um projeto hegemônico nunca será exclusivo (NETTO, 1999, p. 5).

Todavia, independente da dimensão elencada por Netto, não podemos descartar a ideia de que é a partir do momento em que colocamos a hegemonia como uma prevalência, predominância dos interesses de uma maioria, que podemos entendê-la como expressão de um projeto de sociedade, quando este se destaca entre uma diversidade de propostas no processo de disputa de uma direção social, está alicerçada em determinado período histórico, como também, no âmbito do Serviço Social, este conceito se materializa claramente na multiplicidade de experiências de articulação (MOURA, 2015) e da vontade de potência de aliar os objetivos do projeto profissional e de projetos societários que tenham o mesmo direcionamento ético-político. 
Mesmo que o Projeto ético-político, a princípio, seja teleologicamente projetado no campo das ideias, pode-se estabelecer e dar forma a uma profissão, na medida em que se elencam valores, princípios e delineia-se uma imagem desta (NETTO, 2009). Portanto, é a partir da idealização subjetiva que, na prática, tal projeto profissional tem se expressado em aspectos teóricos, posicionamentos políticos, estratégias organizativas e na estruturação de aporte jurídico e normativa. Braz e Teixeira (2009) afirmam:

\begin{abstract}
Num exercício de sistematização, podemos identificar os elementos constitutivos do projeto ético-político do Serviço Social e os componentes que o materializam no processo sócio-histórico da profissão. São eles: a) o primeiro se relaciona com a explicitação de princípios e valores ético-políticos; b) o segundo se refere à matriz teórico-metodológica em que se ancora; c) o terceiro emana da crítica radical à ordem social vigente - a da sociedade do capital - que produz e reproduz a miséria ao mesmo tempo em que exibe uma produção monumental de riquezas; d) o quarto se manifesta nas lutas e posicionamentos políticos acumulados pela categoria através de suas formas coletivas de organização política em aliança com os setores mais progressistas da sociedade brasileira (BRAZ; TEIXEIRA, 2009, p. 192-193).
\end{abstract}

Para tanto, é necessário e salutar, ao falar da natureza de ambos os projetos e de sua maneira de facilmente ser influenciado, modificado e transformado, que este não fique somente no campo da palavra e da idealização, mas sim, seja materializado no campo da "[...] coragem que precisa ser lapidada todos os dias" (RAMOS, 2009, p. 42). Tal coragem é entendida aqui como elemento constitutivo da vontade de potência - que é a capacidade para pensar, criar, produzir, agir e executar a direção social estratégica partindo da intencionalidade do pensamento teleológico à produção concreta de um resultado histórico e social.

Nesse momento, cabe o registro do fenômeno da vontade de potência, não como apropriação de poder, mas como o resultado de um coletivo profissional articulando forças em prol de objetivos em comum, sendo este atualmente captado na dinâmica do movimento do exercício profissional do Serviço Social. A partir deste, podemos inferir que já é posto em prática no seio da categoria, principalmente no enfrentamento ao pensamento pós-moderno, sua estratégia de pegada neoconservadora e de sua agenda pós-neoliberal da contrarrevolução burguesa.

A vontade de potência pode ser percebida no processo de construção do projeto profissional do Serviço Social através das dimensões elencadas por Braz e Teixeira (2009): primeiro, na investigativa e produção de conhecimento; segundo, na político-organizativa; e terceiro, na jurídico-política. Para tanto, tais dimensões têm uma tarefa essencial no projeto profissional que se põe na atualidade com o desafio maior do enfrentamento das investidas do movimento pós-moderno e sua agenda pós-neoliberal, que nos dizeres de lamamoto (2015) é necessário

[...] tornar esse projeto um guia efetivo para o exercício profissional e consolidálo por meio de sua implementação efetiva, ainda que na contramão da maré neoliberal, a partir de suas próprias contradições e das forças políticas que possam somar na direção por ele apontada. Para Tanto, é necessário articular as 


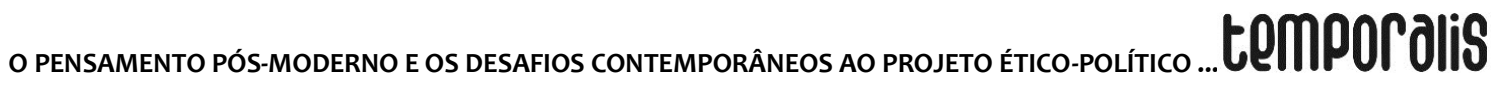

dimensões organizativas acadêmicas e legais que lhe atribuem sustentação com a realidade do trabalho cotidiano (IAMAMOTO, 2015, p. 233).

Atualmente, ainda registra-se uma intenção já iniciada desde a década 1980, através de docentes e/ou pesquisadores, de uma aproximação e apropriação de referenciais teóricos e metodológicos que extrapolem a perspectiva conservacionista do Serviço Social. Hoje, a categoria constitui-se em área de produção do conhecimento, apoiada por organizações voltadas para o fomento à pesquisa no país, como aCoordenação de Aperfeiçoamento de Pessoal de Nível Superior (CAPES), fundação do Ministério da Educação (MEC), já se consolidando especialmente como referência no estudo das políticas públicas no Brasil. Tal movimento ainda se configura incompleto quanto à aproximação de fontes clássicas ou até mesmo do pensamento social crítico na modernidade, no qual entende-se que é saudável a reflexão crítica do exercício profissional, devendo esta ser cultivada, servindo de base para refutação das controvérsias acerca das teorias pós-modernas (IAMAMOTO, 2015).

Ademais, está posto que os valores do projeto ético-político profissional se expressam no fazer profissional de variadas formas (formativa e investigativa, organização política e legal e normativa, que tem tido apoio do conjunto ABEPSS, ENESSO e o CFESS/CRESS e legislações específicas) e que já influencia positivamente a prática profissional nos multicampos em que o Serviço Social atua ou mesmo na formação do saber de outras categorias profissionais.

No caso do Brasil, de acordo com Mota (2009), a categoria profissional do Serviço Social avança em tempos de crise, criando estratégias e reconstruindo seu arcabouço teóricometodológico, dando novos rumos na interlocução entre a emancipação política e o horizonte do alcance de uma emancipação humana, o que reflete positivamente no enfrentamento às teorias pós-modernas e dá sustentação ao novo projeto profissional. Ainda, segundo Mota:

O processo histórico mostra a atuação organizada e coletiva dos assistentes sociais, associados à luta mais geral dos trabalhadores e orientada por um projeto profissional e societário claro, preciso, consistente, fundamentado teórica e politicamente, já propiciou importantes conquistas e solidificou fortes resistências ao desmonte da Seguridade Social. Ainda que estas não tenham sido capazes de alterar significativamente a estrutura de desigualdades sociais, inegavelmente contribuíram no processo de construção dos direitos sociais brasileiros (MOTA, 2007, p. 34).

Para além desse debate, Braz (2007) posiciona-se de forma particular e unilateral em relação à alguns entreves da dimensão formativa em que o projeto profissional se expressa no seio da profissão. Sua polêmica gira em torno da inexistência, de fato, de uma proposta hegemônica da categoria em relação ao Projeto ético-político, de sua crise e decadência diante da complexidade das estruturas e de sua capacidade de influenciar novos projetos societários.

Não há dúvidas de que, hoje, certamente podemos afirmar que o referido projeto profissional do Serviço Social está em pauta e em permanente revisão no seio da profissão. Este é um legado político e aparece explicitamente no campo da produção de 


\section{temporalis}

conhecimento através da direção sociopolítica encampada nas produções acadêmicas e literárias, tendo como exemplo os estudos recentes de teóricas do Serviço Social, como Mota, em Serviço Social brasileiro: insurgência intelectual e legado político (2016); Mota e Amaral, em Projeto profissional e projeto societário (2009); Ramos, em Limites e possibilidades históricas do Projeto ético-político (2009); e Duriguetto e Marro, em Serviço Social, lutas e movimentos sociais (2016), com direcionamento crítico hegemônico no fazer profissional do Serviço Social.

Portanto, parece consensual entre a maioria dos autores que se dedicam ao estudo das dimensões e alcance do projeto profissional, a evidência de que há um esforço para preservação e manutenção do aprofundamento dos ideais do novo projeto profissional articulado aos movimentos sociais de horizonte semelhante rumo a uma nova ordem societária, sendo esta não mais totalitarista, opressora, excludente e/ou discriminatória por questão de etnia, raça ou gênero. De fato, é o que podemos denominar de movimento da vontade de potência na capacidade de materializar os ideais coletivos propostos pelo corpo profissional.

\section{DESAFIOS, VONTADE DE POTÊNCIA E PROJETO PROFISSIONAL}

É no rastro de uma crise orgânica ${ }^{21}$ que a política social brasileira contemporânea traz uma realidade inconsistente, segmentada e pouco expressiva quanto às iniciativas de caráter preventivo e/ou protetivo.

No Estado capitalista, uma peça estrutural e indispensável é o orçamento público ${ }^{22}$, que permite executar as políticas públicas setoriais, buscando atender os diversos interesses das classes sociais. Segundo Salvador (2012), este tem sido, atualmente, um campo de disputa pela apropriação do fundo público e espaço de luta política entre as diversas forças da sociedade, que têm presenciado um atendimento aos interesses privados do capitalismo financeiro a ponto de colocar em xeque a estabilidade do Estado e da execução de políticas públicas que visam a efetivação de um sistema de proteção social no país.

Nesse contexto, os projetos societários e movimentos do projeto profissional do Serviço Social buscam respostas. No âmbito do Serviço Social, a categoria busca, na perspectiva da totalidade, respostas mais rápidas frente às tendências neoconservadoras derivadas do pensamento pós-moderno. Exige-se um profissional inovador, investigativo, reflexivo e propositivo, e que seja crítico diante da realidade social. Do ponto de vista dos sujeitos de

\footnotetext{
${ }^{21}$ A crise orgânica é entendida como fenômeno que se expressa no ambiente econômico, em paralelo ao contexto político. Tal fusão pode redimensionar e transformar a esfera ideológica e cultural refletindo em efeitos negativos seja para classe trabalhadora, seja para o movimento das lutas sociais. Tal crise é gerada no processo de dominação e acumulação do capital, envolvendo tanto as forças produtivas quanto os aparelhos privados para concretização de seus objetivos.

${ }^{22}$ É justamente o orçamento público que garante que a ação do Estado seja executada realmente e de forma planejada. Desde a década de 1980 , que a execução das políticas públicas setoriais é realizada pelo fundo público, dando sustentação econômica e operacional na viabilização destas. No caso brasileiro, temos o fundo público da seguridade social, no qual atualmente vem sendo disputado pelo capitalismo financeiro globalizado, objetivando a manutenção dos interesses da classe burguesa, desvirtuando sua natureza destinada ao atendimento dos interesses da sociedade em geral e enfraquecendo as ações do Estado e das políticas públicas (SALVADOR, 2012).
} 


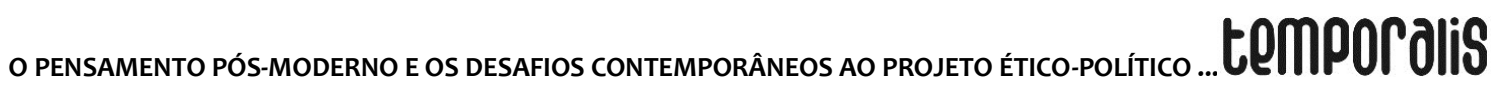

direito, como os usuários da assistência social em geral, faz-se necessário possibilitar aos mesmos espaços de participação e de práticas democráticas.

No geral, é perceptível o desenvolvimento de ações pontuais e da não solução das várias expressões da questão social, as quais expressam intervenções compensatórias com foco na desigualdade social com políticas redistributivas (tapa-buracos) esquecendo que 0 cerne do problema é de ordem sistêmica.

Essas ações, presas a uma concepção residual pelo Estado na gestão do atendimento às necessidades e anseios sociais coletivos, acabam colaborando com disparidades sociais e o alargamento do processo de subcidadãos brasileiros (SANTOS, 1994). Também não respeita o princípio da equidade, estando em consonância com o neoconservadorismo em nome do avanço da acumulação do capital financeiro. Assim, o Estado, ao transferir suas responsabilidades e competências para organizações do terceiro setor, fazendo ressurgir o processo de refilantropização e a privatização dos serviços públicos, fragiliza, consequentemente, a consolidação da cultura de sujeitos de direito. A lógica dessa apropriação do espaço e do fundo público é que ambos os campos trabalham na perspectiva da benemerência, do favor e da ajuda aos necessitados, como também para obtenção de lucro, como explicitado por Duriguetto e Montaño (2011).

Por conseguinte, Duriguetto ainda lança a seguinte afirmativa de que

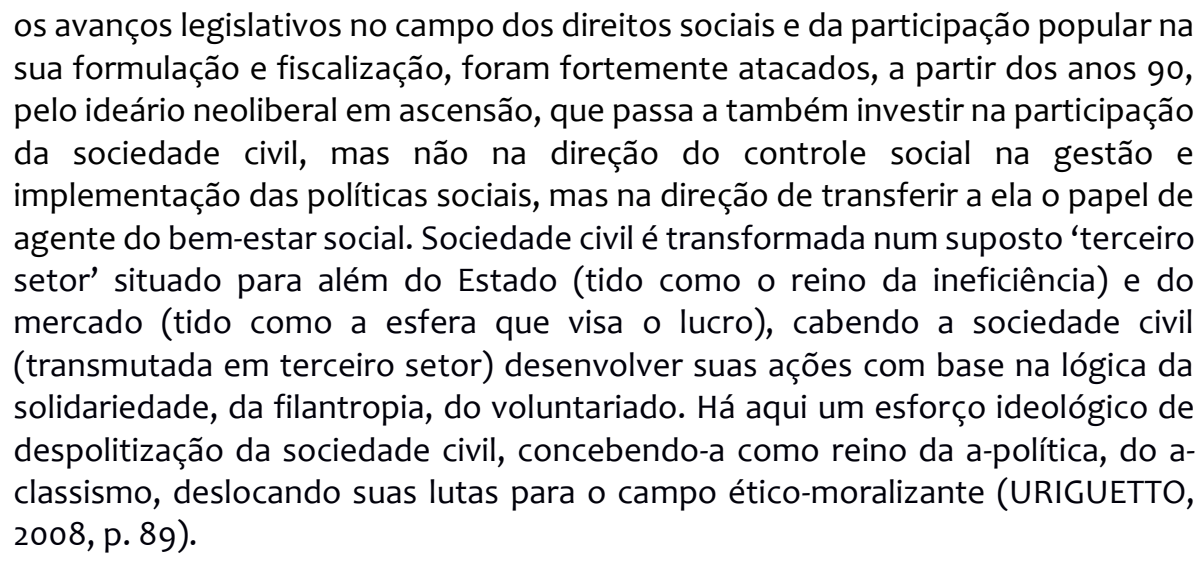

Segundo Duriguetto, é no campo do a-classismo e do a-politismo que se expressa como tendência geral a restrição e redução da oferta de direitos sociais (indício este que reflete na não linearidade construtiva da esfera da cidadania). Sendo assim, são sujeitos que, principalmente a partir da década de 1990, não buscaram e podem não querer mais hoje optar por vias alternativas para o enfrentamento de ofensivas do neoliberalismo.

Tais rebatimentos são entendidos e sentidos como entraves em diversos setores da sociedade: a) na esfera financeira - prevalecendo políticas sociais de caráter privatistas mercantilização de entidades públicas brasileiras, acentuado com o processo de desnacionalização expressa pela venda de bens públicos nacionais para o estrangeiro (DINIZ; BOSCHI, 2007); b) no campo do trabalho - com a flexibilização das relações de trabalho e o desemprego em escala mundial, assumindo novas configurações através de postos temporários e intermitentes, parciais e polivalentes (ANTUNES, 1995); c) no modelo 


\section{temporalis}

de proteção social - com a descaracterização do conceito de universalidade de acesso às políticas públicas por meio do recorte de classe social, ou seja, para os mais vulneráveis ou os bolsões de extrema pobreza, denominada de focalização, segundo Yazbek (2011); e d) no caráter das políticas públicas - com a privatização a partir dos processos de refilantropização e terceirização das políticas públicas a todo vapor, junto à descentralização - esta não no sentido de compartilhamento do poder decisório do Estado, mas sim, pela mera transferência de responsabilidade do Estado para entes da federação ou organizações sociais fora do corpo estatal (MONTAÑO; DURIGUETO, 2011).

Interligado ao contexto explicitado acima, tem-se, no processo de desmonte e fragmentação das políticas públicas que formam o sistema de seguridade social brasileiro, as seguintes relações que podem trazer entraves para a construção da identidade dos sujeitos de direito na contemporaneidade: I) de solidariedade e voluntarismo de pegada cristã; II) da tríade privatização/focalização/seletividade - rumo ao desespero e desamparo social (daqueles que, mesmo necessitando delas por determinada limitação, não conseguem acessá-las); e III) da desresponsabilização do Estado por seu dever na efetivação dos direitos sociais e na ampliação da concentração de renda das classes dominantes (BEHRING; BOSCHETTE, 2011).

Diante desse cenário, rodeado por essas contradições da ordem social contemporânea, é que o projeto ético-político do Serviço Social tem montado, como estratégia de resistência aos postulados do pensamento pós-moderno, a luta na perspectiva de romper com segmentos conservadores e contrarrevolucionários tradicionalistas. Esses postulados são influenciados desde o movimento da Revolução Francesa, tendo como referencial as ideias de autores como Edmund Burke, e de pós-modernos como o estruturalista Anthony Giddens, com sua teoria da 'terceira via'; do sociólogo estrutural Ulrich Beck, com sua ideia acerca da sociedade de risco; e, por fim, de Karl Poper, com sua teoria da refutação na área da produção de conhecimento. A junção desses pressupostos não mede esforços para distanciar-se das vertentes marxistas e neomarxistas.

Essas estratégias são enfrentadas pelo Serviço Social em contexto global e brasileiro frente ao pensamento pós-moderno, tanto no que se refere à tentativa de desorganização de um direcionamento social e político que venha a corroborar para a estruturação da hegemonia nas lutas coletivas e populares, quanto no âmbito da seguridade social mediante o desmantelamento de sua estrutura e de seus princípios. Um exemplo é o princípio da universalidade do acesso a bens e serviços gratuitos pela sociedade, modificando a natureza do padrão público de programas de proteção social. Tais fatores anteriormente citados são postos, segundo Behring (2011), pelo neoliberalismo e se apresentam como uma ofensa à inviolabilidade dos direitos dos cidadãos dentro de um modelo democrático de Estado, configurando-se como retrocesso para a consolidação de uma cidadania plena no Brasil. Segundo Silva, Jaccoud e Beghin (2005), este fato vem sendo registrado no contexto brasileiro de forma mais acentuada a partir da década de 1990.

A partir do exposto acima, pode-se inferir que é na contenda entre a relação Estado e sociedade que temos presenciado investidas ferinas no âmbito das estratégias colocadas pela agenda denominada de pós-neoliberal permeadas pelas ideologias pós-modernas na dilapidação dos direitos de cidadania e da ampliação e consolidação das bases do Estado 


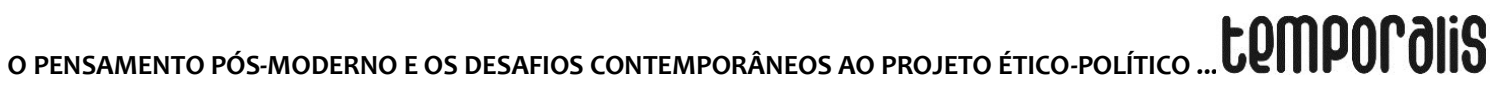

democrático. Com isso, percebe-se a influência, na atual conjuntura brasileira, não só de mudanças estruturais, mas também macroeconômicas, as quais se revelam em traços antigos, seja no ajustamento fiscal, flexibilização das legislações (desregulamentação), seja na abertura comercial hospitaleira aos investimentos estrangeiros e do incentivo aos processos de privatização de bens e serviços públicos (PINHEIRO, 2003), formando assim um cenário que caracteriza o enquadramento econômico, político e social do neoliberalismo, denominado pelos teóricos contemporâneos das ciências políticas e econômicas de agenda pós-neoliberal.

Decerto, é diante dos referidos retrocessos no campo da Seguridade Social Pública, no processo da contrarreforma do Estado brasileiro, com a investida de políticas públicas forçosamente implementadas de cima para baixo (modelo Top-Down), que põe em xeque direitos historicamente conquistados no campo social, os quais vêm sendo retirados. Como exemplo concreto, tem-se a PEC 241, que se refere às Políticas de Saúde e de Educação, que o governo do presidente Michel Temer conseguiu que fosse aprovado no Congresso Nacional, estabelecendo o congelamento de investimentos financeiros durante duas décadas seguidas, tendo como argumentação a estabilidade econômica, do necessário aumento do investimento na saúde privada e retorno do crescimento do país. Um outro exemplo é o processo de reforma da Política Previdenciária e Trabalhista imposto pelo governo Temer, mesmo com a insatisfação e a mobilização nas ruas da classe trabalhadora. Como resultado, temos a indignação e o descontentamento popular.

Dessa maneira, o Estado brasileiro ao mesmo tempo em que se utiliza do fundo público para legitimar interesses do capital financeiro, usa uma pequena parcela deste para desenvolver programas sociais que garantem claramente a inclusão do cidadão na cadeia de consumo (CARVALHO; GUERRA, 2016). Com isso, vivenciamos um momento em que o governo do presidente Michel Temer levanta a bandeira explicita de um Estado ajustador que coaduna com o conservadorismo ortodoxo do capital financeiro globalizado, pondo em xeque o fundo público das políticas públicas e ampliando as desigualdades sociais no Brasil.

No tocante à atual situação da Política de Assistência Social brasileira, segundo Yazbek (2011), esta vem sendo acometida por recortes financeiros, se configurando como mera atenuadora da pobreza extrema e contra seus princípios e diretrizes, tendo como resultado ações fragmentadas e programas sociais residuais. Outro elemento tem sutilmente ganhado força desde 2003 até os dias atuais no embate da ideia da crise de hegemonia e da possível inviabilização do projeto profissional, sustentado na questão da redução do horizonte profissional na atuação e gestão tão somente da política de assistência social, como se esta bastasse como solução de todos os problemas avindos das desigualdades sociais (NETTO, 2007). Por isso que há uma necessidade da apropriação do aparelho estatal por parte da classe trabalhadora em geral, no sentido de reordenar os recursos públicos de maneira que estes, por hora, não sejam trabalhados de forma estritamente técnica, mas sim, como uma ferramenta de planejamento e ético-política tanto para subsidiar as negociações para manutenção e implementação de novos direitos sociais quanto estratégia de transição para outro modelo de sociedade (SALVADOR, 2012). 


\section{tempordlis}

Para tanto, é imprescindível que a Política de Seguridade Social seja apta para alcançar padrões de civilidade, começando na garantia de direitos no sistema capitalista, como já registradas nas estratégias de enfrentamento na Carta de Maceió, cujo principal objetivo é "[...] assegurar os princípios da universalidade, da cidadania, da democracia e da justiça social, obter informações relevantes para a luta social e promover a articulação política no âmbito da sociedade civil" (CONSELHO FEDERAL DE SERVIÇO SOCIAL, 2000, p. 3). Por isso, uma Seguridade Social montada estrategicamente em defesa de uma democracia popular no Brasil, por intermédio de movimentos sociais, luta geral dos trabalhadores e da sociedade em geral, pode e deve construir bases justas e equitativas, vistas não como horizonte final, mas como uma alternativa transitória de padrões sociais e de garantia de direitos na sociedade capitalista, buscando ultrapassar o suprimento apenas de necessidades básicas e de sobrevivência humana (BEHRING; BOSCHETTI, 2016).

Ademais, ao considerarmos o conjunto dos processos transformativos, verifica-se que o Estado brasileiro, durante sua reestruturação nas últimas três décadas, tem assumido o papel de mero corretor de desequilíbrios de ordem econômica em momentos de crise do capital. Ao dar livre movimento e apoio às ações do mercado e dos interesses deste, desencadeou o processo de enxugamento do Estado diante dos cortes das políticas públicas, especialmente saúde, educação e assistência social, que contemplasse de forma satisfatória as reais necessidades da sociedade. Consequentemente, isto tem alargado ainda mais as desigualdades sociais em países como o Brasil.

Nessa perspectiva, tanto os processos estruturais locais quanto os macroeconômicos, têm modificado, mesmo que indiretamente, o desenho das políticas públicas setoriais no Brasil. Ao invés de serem planejadas visando assegurar os direitos sociais, têm se tornado um mecanismo estratégico para manutenção e ampliação das taxas de crescimento econômico no país, dando sentido oposto à finalidade a qual deveria ter de fato.

Diante do exposto, apontamos dois vetores de força negativa como entraves da incorporação de segmentos profissionais da categoria de assistentes sociais no processo de articulação interna, na ampliação dos ideais e implementação do novo projeto profissional, na perspectiva da adesão com outras categorias profissionais no tocante a novos horizontes societários em comum: o primeiro vetor está no fato da formação de uma esquerda brasileira que aderiu ao neoliberalismo e sua agenda pós-neoliberal, passando a reproduzir o ideário antirrevolucionário socialdemocrata; e o segundo vetor está na aderência ao processo de mercantilização da formação profissional, que vem degradando, massificando e colocando em risco os rumos de viabilização do projeto ético-político do Serviço Social e de sua direção social e política, diante de uma rápida ampliação da educação privada no país voltada apenas para atender às necessidades mercadológicas, distanciando-se das vertentes do pensamento social crítico (NETTO, 2007).

Netto também deixa claro que as dificuldades e desafios anunciados em seu texto "Das ameaças à crise", acerca da temática explorada neste artigo, atualmente se concretizaram, ganhando força justamente por colocar em tensão o novo projeto profissional na disputa entre os interesses das classes sociais, de maneira que "[...] o seu enfrentamento supõe mais vontade política organizada e menos ilusões otimistas" (NETTO, 2007, p. 40). Além disso, Mota acrescenta que 


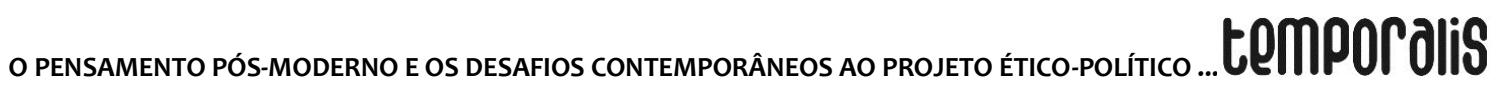

[...] entender que a relação entre os princípios, valores e as ações para sua realização dependem da compreensão das dimensões e do significado do Projeto Ético-Político; da disposição teórica e ideológica de assumi-lo; da identificação das condições objetivas e subjetivas predominantes em cada contexto histórico; e da construção de alianças estratégicas com outros profissionais, usuários e trabalhadores que têm como projeto uma sociedade justa, igualitária e capaz de autodeterminar seu futuro (MOTA, 2007, p. 35).

Para explicar melhor a ideia de crise de hegemonia nos projetos societários, argumento este defendido por Netto (2007), parte-se da tese de Viana (1996), de que o processo de construção e consolidação da cidadania no Brasil, elemento base para impulsionar os projetos societários, não se deu nos moldes tradicionais, como no caso da Revolução Francesa, mas "[...] voltando os olhos para as atividades e a significação histórica da Comuna de Paris de 1871 [...]" (MARX, 1999, p. 16) que, diante da indignação da classe burguesa, sendo esta constituída pela sociedade civil, buscou a ampliação dos seus direitos na época.

Além disso, tal burguesia revolucionária, em um primeiro momento, reconheceu que no processo de compartilhamento de poder, a classe operária deveria governar se desprendendo dos velhos e nocivos mecanismos repressivos do aparelho estatal e da necessidade de criar estratégias para evitar as investidas de contrarreformas ou de dominação de poder político frente à implementação de novas bases de sociabilidade, propostas pelo modelo organizativo da Comuna de Paris. Todavia, tal exemplo não logrou êxito na época, pois a burguesia revolucionária se aliou aos representantes da velha elite monárquica (latifundiários, absenteístas, antigos escravistas e ex-proprietários de servos), liderados pelo Marechal Bismarck, cidadão alemão que ordenou a população a roubar, matar e queimar os 64 reféns da Comuna, tragédia denominada carnificina de Paris. Esse fato, segundo Marx (1999), impossibilitou o desenvolvimento dos ideais de um projeto de sociedade novo, símbolo histórico mais expressivo de sociedade democrática plena.

Portanto, pode-se concluir que nunca houve de fato uma revolta realmente burguesa no Brasil, onde a classe popular tenha prevalecido. Segundo Vianna (1996), o que houve no Brasil foi uma revolução passiva e guiada pelo alto, dificultando os processos de efetivação e os exercícios de implantação e ampliação de projetos societários ou profissionais que se oponham à ordem social vigente.

Mesmo assim, é no rastro do legado soció-histórico de oito décadas do Serviço Social no Brasil, que podemos nos valer de sua capacidade de construção e reconstrução em permanente movimento, baseado nas raízes do pensamento crítico dialético marxista, para por em práticas os processos transformativos, chocando-se frontalmente com o pensamento pós-moderno que considera o Marxismo ultrapassado, velho e retórico, constituindo hoje um problema para os pensadores burgueses contemporâneos, justamente pelo pensamento crítico basear-se em metanarrativas, segundo explicitação de Netto (2016).

Não é à toa que o autor citado acima defende a tese de que está se formando, atualmente, entre a categoria profissional, uma hipertrofia de estudos localizados e particulares de 


\title{
temporalis
}

médio e curto alcance, que se distanciam da captação da história do Serviço Social como legado sócio-histórico, ao passo que há atrofia das abordagens históricas ampliadas que dão conta da dinâmica macroscópica, incluindo os registros do Serviço Social. Com isso, ratifica que há indícios de que o pensamento pós-moderno já esteja influenciando o campo da produção de conhecimento na medida em que começa a fragmentar os estudos de totalização histórica e, também, que estamos rumo a uma crise de hegemonia no âmbito do projeto profissional indo na contramaré dos estudos já explicitados neste artigo, em defesa da seguinte afirmativa:

\begin{abstract}
Há fortíssimas indicações de que, mesmo dando-se por suposto que a hegemonia do projeto ético-político não se encontra em causa, atrofia-se o labor do histórico analítico que tem por objeto o processo de constituição e, parcialmente, do desenvolvimento do nosso Serviço Social - labor que, reitere-se, está entre os fundamentos do projeto. Uma tal atrofia [...] afeta significativamente a incidência da pesquisa histórica no direcionamento social da profissão e pode sinalizar [...] uma inflexão na direção social que se considera hegemônica. Penso que essa atrofia não pode ser divorciada da emergência de vetores ideopolíticos e teóricometodológicos que, sobretudo indiretamente, põem em questão a substancialidade do projeto ético-político (NETTO, 2016, p. 65).
\end{abstract}

Mesmo assim, Mota (2016), em contraposição expressa aos novos indícios no campo da produção do conhecimento que sinaliza o Serviço Social não como atrofia, mas sim, como referência na construção de pontes culturais, ideológicas e políticas do pensamento de esquerda no Brasil, ressalta uma nova questão no movimento da profissão - a existência de pesquisadores e estudiosos que procuram amparo na teoria social crítica do Serviço Social no Brasil alinhado ao pensamento marxista, lukacsiano e gramisciano, na medida do descontentamento com a razão instrumental e pós-moderna que permeiam as ciências sociais e político-econômicas.

Contudo, é importante frisar que parece consensual a luta pela expansão das políticas sociais e dos direitos por elas assegurados, sendo um elemento fundamental central e indissociável da constituição da liberdade e emancipação humana no tecido social e base para a consolidação do projeto ético-político do Serviço social brasileiro, que sinaliza ter, hoje, como arma ascendente, a vontade de potência nas diversas dimensões em que se apresenta.

Por fim, mesmo com registros de vitórias no campo da produção do conhecimento e político-organizativo, Souza (2016) reverbera que para uma aproximação dos objetivos de uma nova ordem societária, devem-se combater urgentemente duas vertentes do neoconservadorismo que ultimamente vem corroendo as bases de um Estado democrático e de novos projetos de sociedade e/ou profissionais, são eles: a) a hipocondria da antipolítica - caracterizada como uma síndrome que acomete os movimentos políticos quando há uma sequência de derrotas, resultando no abandono de teorias revolucionárias; b) a política de conciliação de classes - esta considerada impossível na ordem organizativa do capital, sendo tal desprendimento considerado estratégia concreta do ponto de vista da ruptura com o neoconservadorismo e da consequente desarticulação da base lógica de modelo de reprodução da condição sociometabólica destrutiva do modo de produzir do capital. 


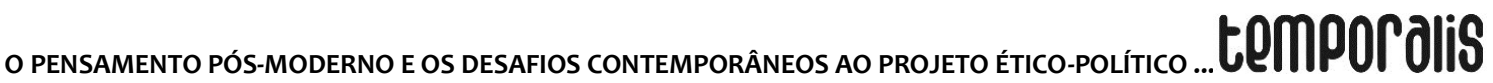

\section{CONSIDERAÇÕES FINAIS}

É evidente que o conjunto dos fenômenos explicitados neste artigo - tendências pósmodernas, agenda pós-neoliberal e suas estratégias neoconservadoras de inspiração conservadora clássica, derivadas de ideias de autores como Edmund Burke ou mesmo das contemporâneas, com base em perspectivas teóricas estruturalistas da terceira via, de Anthony Giddens, da sociologia do risco de Ulrich Beck e da refutação de metanarrativas de Karl Poper na produção do conhecimento, têm reverberado indiretamente em entraves que podem afetar o processo de concretização tanto de projetos societários quanto de projetos profissionais que, diante da complexidade de tais desafios, que não são poucos, mesmo assim pode-se inferir que existe uma direção social que embasa o movimento do projeto adotado pela categoria profissional do Serviço Social na efetivação dos princípios e diretrizes norteadores do direcionamento social estratégico.

Tal afirmativa revela indícios de que há uma hegemonia quanto à direção sociopolítica do projeto profissional, porém, este não pode ou não deve descansar no horizonte de uma nova sociabilidade, na medida em que os elementos para fomentar uma futura crise já circulam nas dimensões onde o Serviço Social atua: na produção do conhecimento através da fragmentação do ensino por meio da separação do processo ensino, pesquisa e extensão, da atrofia de estudos de abrangência sócio-histórica e da privatização e mercantilização do ensino, principalmente com o avanço da oferta de cursos a distância, o que em longo prazo pode interferir na direção sociopolítica da categoria; na prática político-organizativa - com o pavor e a descrença nas metanarrativas diante da aderência a postulados pós-modernistas e no cotidiano do exercício profissional da prática indiferenciada neoconservadora - seja restaurando a base sincrética do Serviço Social (questão social/cotidiano/manipulação de variáveis empíricas) ou mesmo resgatando traços do pensamento formal-abstrato que dão o tom pragmático, moralista, psicologizante e/ou do ecletismo.

Nessa perspectiva, acreditamos que o mais relevante, por hora, é entendermos que estamos diante de um momento em que a categoria, para além de se gladiar em um debate dual do certo ou errado na tentativa de provar uma possível crise de hegemonia ou não no direcionamento social do projeto ético-político, estes devem e podem, na unidade de diversos, somar forças diante das investidas da reação burguesa na manutenção de seu projeto de sociedade, diante do registro de que o Serviço Social brasileiro tem adquirido maturidade intelectual e robustecido o campo político-organizativo. Diante disso, para colocar em prática os objetivos do projeto profissional tem-se a necessidade urgente da apreensão da vontade de potência como elemento constitutivo de uma massa crítica do Serviço Social, seja como elemento unificador da referida categoria, seja como ferramenta que dá significação à luta coletiva na estruturação por novos horizontes socioculturais.

Seguindo as mesmas diretrizes, Mészáros (2011) aponta dois caminhos para a transformação radical da sociedade: a abolição do modelo político vigente e a completa reorganização estrutural das relações de trabalho, extinguindo o trabalho explorador assalariado (não aceitando mais negociações da política conciliadora das classes sociais). Aliado a isso, a apropriação do Estado e de sua estrutura econômica deve ser executada como estratégia transitória por meio do alargamento do fundo público, rumo à 
implementação de um sistema de proteção social diferenciado, desregulamentando a natureza do Estado Ajustador.

Portanto, percebe-se que é no movimento da vontade de potência da categoria profissional, ou seja, da coragem no exercício diário de repensar um projeto de sociedade democrático na contemporaneidade, vislumbrando para além de uma visão estritamente tecnicista, imediatista e pragmática, e de suas expressões nos diversos contextos, que se deve começar a implementar o processo de radicalização dos ideais dos onze princípios contidos no código de ética profissional do Serviço Social e dos objetivos da Carta de Maceió, corroborando para acelerar os processos de transição societária e também dar sustentação ao posicionamento explícito contrário a uma sociedade que é conhecida como a sociedade da crise.

\section{REFERÊNCIAS}

ABBAGNANO, Nicola. Dicionário de filosofia. 2. ed. São Paulo: Mestre Jou, 1982.

ABRAMIDES, Maria Beatriz Costa. O projeto ético-político profissional do Serviço Social brasileiro. Tese (Doutorado em Serviço Social)-Programa de Pós-Graduação em Serviço Social, Pontifícia Universidade Católica, São Paulo, 2006.

ANTUNES, Ricardo. Adeus ao trabalho? Ensaio sobre as metamorfoses e a centralidade no Mundo do Trabalho. São Paulo: Cortez, 1995.

ASSOCIAÇÃO BRASILEIRA DE ENSINO E PESQUISA EM SERVIÇO SOCIAL. Diretrizes gerais para o curso de Serviço Social de 1996. Rio de Janeiro, 1996. Disponível em: <http://www.abepss.org.br/arquivos/textos/documento_201603311138166377210.pdf>. Acesso: 10 abr. 2018.

BARROCO, Maria Lucia Silva. Barbárie e neoconservadorismo: os desafios do projeto ético-político. Revista Serv. Soc. Soc., São Paulo, n. 106, p. 205-218, abr./jun. 2011.

BRAZ, Marcelo et al. A hegemonia em xeque. Projeto ético-político do Serviço Social e seus elementos constitutivos. Revista Inscrita, Brasília: CFESS, ano 7, n. 10, p. 5-10, 2007.

BRAZ, Marcelo; TEIXEIRA, Joaquina Barata. O projeto ético-político do Serviço Social. In: BOSCHETTI, Ivanete Salete et al. (Org.). Serviço Social: direitos e competências profissionais. Brasília: Conselho Federal de Serviço Social; Associação Brasileira de Ensino e Pesquisa em Serviço Social, 2009. p. 185-200.

BRASIL. Conselho Federal de Serviço Social. Carta de Maceió. Alagoas: CFESS, 2000. Disponível em: <http://www.cfess.org.br/arquivos/encontronacional_cartas_maceio.pdf >. Acesso em: 3 mar. 2018.

BRASIL. MINISTÉRIO DA EDUCAÇÃO E DO DESPORTO. Diretrizes curriculares elaboradas pela equipe de especialistas de 1999. Brasília (DF), 1999. Disponível em: 


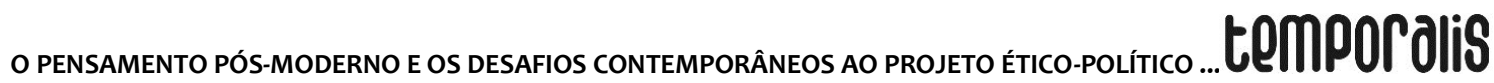

<http://www.abepss.org.br/arquivos/textos/documento_201603311140412406970.pdf >. Acesso em: 18 abr. 2018.

BRASIL. Ministério da Educação. Diretrizes Curriculares para os Cursos de Serviços Sociais aprovada pelo MEC em 2002. Resolução $n^{\circ}{ }_{15}$, de 13 de março de 2002. Disponível em:

<http://www.abepss.org.br/arquivos/textos/documento_201603311141012990370.pdf>. Acesso em: 18 abr. 2018.

BEHRING, Elaine Rossetti; BOSCHETTI, Ivanete S. Política Social: fundamentos e história. São Paulo: Cortez, 2011.

BEHRING, Elaine Rossetti; BOSCHETTI, Ivanete. Serviço Social e política Social: 80 anos de uma relação visceral. In: SILVA, Maria Liduína de Oliveira (Org.). Serviço Social no Brasil: história de resistências e de ruptura com o conservadorismo. São Paulo: Cortez, 2016.

BUCI-GLUCKSMANN, Christinne. Gramsci e o estado: por uma teoria materialista da filosofia. Tradução de Angelina Peralva. Rio de Janeiro: Paz e Terra, 1980.

CARDOSO, Priscila Fernanda Gonçalves; TORRES, Andrea Almeida. Rupturas, desafios e luta por emancipação. In: SILVA, Maria Liduína de Oliveira (Org.). Serviço Social no Brasil: história de resistências e de ruptura com o conservadorismo. São Paulo: Cortez, 2016.

CARVALHO, Alba Pinheiro de; GUERRA, Eliane Costa. Brasil no século XXI na geopolítica da crise: para onde apontam as utopias? Revista Políticas Públicas, São Luiz, número especial, p. 267-280, 2016.

CONSELHO FEDERAL DE SERVIÇO SOCIAL. Parâmetros para atuação de assistentes sociais na Política de Assistência Social. Brasília: CFESS, 2011.

DINIZ, Eli; Boschi, Renato R.A difícil rota do desenvolvimento: empresários e a agenda pós-neoliberal. Belo Horizonte: Ed. UFMG; IUPERJ, 2007.

DURIGUETTO, Maria Lúcia. Sociedade civil e democracia: um debate necessário. Revista Libertas, Juiz de Fora, v. 8, n. 2, p.83-94, 2008.

DURIGUETTO, Maria Lúcia; MARRO, Katia. Serviço Social, lutas e movimentos sociais: atualidade de um legado histórico que alimenta os caminhos de ruptura com o conservadorismo. In: SILVA, Maria Liduína de Oliveira (Org.). Serviço Social no Brasil: história de resistências e de ruptura com o conservadorismo. São Paulo: Cortez, 2016.

GRUPPI, Luciano. O conceito de hegemonia em Gramsci. Tradução de Carlos Nelson Coutinho. 2. ed. Rio de Janeiro: Graal, 1980.

HARVEY, David. Condição Pós-moderna: uma pesquisa sobre as origens da mudança cultural. São Paulo: Loyola, 1992. 


\section{temporalis}

IAMAMOTO, Marilda Villela. Serviço Social em tempo de Capital Fetiche: capital financeiro, trabalho e questão social. São Paulo: Cortez, 2015.

JAMESON, Fredric. Pós-Modernismo: a lógica cultural do capitalismo tardio. São Paulo: Ática, 1996.

LUKÁCS, György. Ontologia do Ser Social: o Neopositivismo. Revista Teoria e Política, São Paulo, n. 9, 1988.

MARX, Karl. A guerra civil na França. RocketEdition, 1999. Disponível em:

<http://www.ebooksbrasil.org/adobeebook/guerracivil.pdf>. Acesso em: 22 mar. 2018.

MÉSZÁROS, István. Para além do capital: rumo a uma teoria da transição. São Paulo: Boitempo, 2011.

MONTAÑO, Carlos; DURIGUETO, Maria Lúcia. Estado, Classe e Movimento Social. São Paulo: Cortez, 2011.

MOTA, Ana Elizabete. Serviço Social Brasileiro: insurgência intelectual e legado político. In: SILVA, Maria Liduína de Oliveira (Org.). Serviço Social no Brasil: história de resistências e de ruptura com o conservadorismo. São Paulo: Cortez, 2016.

MOTA, Ana Elizabete. A centralidade da Assistência Social na Seguridade Social brasileira nos anos 2000. In: MOTA, Ana Elizabete (Org.). O mito da Assistência Social: ensaios sobre Estado, Política e Sociedade. São Paulo: Cortez, 2010.

MOTA, Ana Elizabete. Seguridade Social pública ainda é possível! Revista Inscrita. Brasília: CFESS, Ano VII, nº X, p. 31-36, 2007.

MOTA, Ana Elizabete; AMARAL, Ângela. Projeto profissional e projeto societário. Revista Inscrita, Brasília: CFESS, ano 8, n. 12, p. 49-55, 2009.

MOURA, Jackeline da Silva. Atualização contemporânea sobre o debate da crise de hegemonia do projeto ético-político do Serviço Social. In: ENCONTRO INTERNACIONAL DE POLÍTICA SOCIAL, 3., 2015 e 10 ENCONTRO NACIONAL DE POLÍTICA SOCIAL, 10., 2015, Vitória. Anais... Vitória, 2015. Disponível em:

<http://periodicos.ufes.br/EINPS/article/view/9967/6981>. Acesso em: 11 mar. 2018.

NETTO, J. P. Para uma história nova do Serviço Social no Brasil. In: SILVA, Maria Liduína de Oliveira (Org.). Serviço Social no Brasil: história de resistências e de ruptura com o conservadorismo. São Paulo: Cortez, 2016.

NETTO, J. P. Das ameaças a crise. Revista Inscrita, Brasília: Conselho Federal de Serviço Social, v. 7, n. 10, p. 37-40, 2007. 


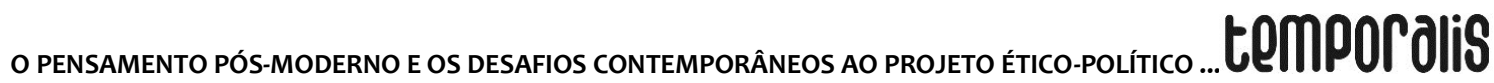

NETTO, J. P. A construção do Projeto Ético-Político do Serviço Social. In: MOTA, Ana Elizabete et al. (Org.). Serviço Social e Saúde: formação e trabalho profissional. São Paulo: Cortez, 1999.

NETTO, J. P. Transformações societárias e Serviço Social: notas para uma análise prospectiva da profissão no Brasil. Serviço Social \& Sociedade, São Paulo: Cortez, n. 50, p. 87-132, 1996.

NIETZSCHE, Friedrich Wilhelm. Além do bem e do mal ou prelúdio de uma filosofia do futuro. São Paulo: USP, 1985.

OLIVEIRA, Maria Tereza de. 0 senso comum como ponto de partida para a filosofia da práxis em Gramsci. Dissertação (Mestrado em Filosofia) - Universidade Federal de Pernambuco, Recife, 1996.

PINHEIRO, Armando Castelar. Uma agenda pós-liberal de desenvolvimento para o Brasil. Rio de Janeiro: IPEA, 2003.

RAMOS, Sâmya Rodrigues. Limites e possibilidades históricas do Projeto ÉticoPolítico.Revista Inscrita, Brasília: CFESS, ano 8, n. 12, p. 41-48, 2009.

SANTOS, Wanderley Guilherme. Cidadania e justiça: a política social na ordem brasileira. Rio de Janeiro: Campus, 1994.

SALVADOR, Evilasio. Fundo Público e o financiamento das políticas sociais no Brasil. Serviço Social em Revista, v. 14, n. 2, p. 4-22, 2012.

SOUZA, Jamerson Murillo Anunciação de. Tendências ideológicas do conservadorismo. Tese (Doutorado em Serviço Social) - Universidade Federal de Pernambuco, CCSA, 2016.

SILVA, Frederico Barbosa; JACCOUD, Luciana; BEGHIN, Nathalie. Questão social e políticas sociais no Brasil contemporâneo. In: INSTITUTO DE PESQUISA ECONÔMICA APLICADA. Políticas sociais no Brasil: participação social, conselhos e parcerias.Brasília: IPEA, 2005.

TERNAS, Richard. A epopeia do pensamento ocidental: para compreender as ideias que moldaram a nossa visão de mundo. Rio de Janeiro: Bertrand Brasil, 2008.

VIANNA, L. W. Caminhos e descaminhos da revolução passiva à brasileira. Revista Scielo Brasil, Rio de Janeiro, v. 39, n. 3, 1996.

VIOLA, Eduardo; FANCHINE, Matias. Sistema internacional de hegemonia conservadora: o fracasso da Rio + 20 na governança dos limites planetários. Revista Ambiente \& Sociedade, São Paulo, [versão on-line], v.15, n. 3. 2012.

YAZBEK, Maria Carmelita. O Sistema Único de Assistência Social: uma realidade em movimento. São Paulo: Cortez, 2011. 